\title{
Comparative Performance Analysis of Urised 3 and DIRUI FUS-200 Automated Urine Sediment Analyzers and Manual Microscopic Method
}

\author{
Urised 3 ve DIRUI FUS-200 Otomatik Idrar Sediment Analizörlerinin \\ Karşılaştırmalı Performans Analizi ve Manuel Mikroskopik Yöntem
}

\author{
Emre YALCINKAYA $\odot$, Hayriye ERMAN $\odot$, Eray KIRAC $\odot$, Afife SERIFOGLU $\odot$, Alperen AKSOY $\odot$ \\ Ferruh K. ISMAN $\odot$, Mustafa B. CEKMEN $\odot$
}

Ethics Committee Approval: This study approved by the Istanbul Medeniyet University, Goztepe Training and Research Hospital, Clinical Studies Ethics Committee, 6 June 2017, 2017/0200. Conflict of interest: The authors declare that they have no conflict of interest. Funding: None.

Informed Consent: Not Applicable.
Cite as: Yalcinkaya E, Erman H, Kirac E, et al. Comparative performance analysis of Urised 3 and DIRUI FUS-200 automated urine sediment analyzers and manual microscopic method. Medeniyet Med J. 2019;34:244-51.

\begin{abstract}
Objective: Microscopic examination of urine sediment is necessary for evaluation of renal and urinary tract diseases. In this study, we evaluated and compared analytic and diagnostic performances of DIRUI FUS-200 and a new image-based automated urine sediment analyzer Urised 3. Method: A total of 440 urine samples, submitted to our laboratory, were evaluated by two automated urine sediment analyzers and a standardized manual microscopy. Precision, linearity and method comparison studies were performed according to CLSI guidelines.

Results: Considering the red blood cell (RBC) and white blood cell (WBC) counts, strong correlations existed between FUS-200 and manual microscopy ( $r=0.993$ vs 0.861$)$, Urised 3 and manual microscopy ( $r=0.962$ vs 0.818), FUS200 and Urised 3 ( $r=0.961$ vs 0.961). Clinical nonconcordance ranged from $7 \%$ to $14.16 \%$ among all methods.

Conclusions: The concordance between the analyzers and manual microscopy for WBC was better than that of RBC. The concordance between the two analyzers was better for WBC and RBC, with respect to the manual microscopy. Although the Urised 3, FUS-200 and manual microscopy counts were in agreement; confirmation of the results of automated analyzers with manual microscopy is particularly helpful, for pathological samples with near cut-off values.
\end{abstract}

Keywords: Automated urine sediment analyzer, DIRUI FUS-200, Urised 3, manual urine sediment analysis, comparative performance analysis

öz

Amaç: Böbrek ve idrar yolu hastalıklarının değerlendirilmesinde idrar sedimentinin mikroskobik analizi gereklidir. Bu çalışmada, DIRUI FUS-200'ün ve yeni bir görüntü tabanlı otomatik idrar sediment analizörü olan Urised 3 'ün analitik ve diagnostik performanslarını değerlendirdik ve karşılaştırdık.

Yöntem: Laboratuvarımıza gönderilen 440 idrar örneği her iki otomatik idrar sediment analiz cihazı ve standart manuel mikroskopi ile değerlendirildi. Kesinlik, linearite ve yöntem karşılaştırma çalışmaları CLSI kılavuzlarına göre yapıldı.

Bulgular: Eritrosit (RBC) ve lökosit (WBC) sayımları düşünüldüğünde; FUS-200 ile manuel mikroskopi arasında (sırasıyla $r=0,993$ ile 0,861); Urised 3 ve manuel mikroskopi arasında (sırasıyla $r=0,962$ ve 0,818); FUS200 ve Urised 3 arasinda (sırasıly $r=0,961$ ve 0,961) güçlü korelasyon vardı. Klinik uyumsuzluk tüm yöntemler arasında $7 \%$ ile $14,16 \%$ arasında değissmekteydi. Sonuç: WBC için analizörler ve manuel mikroskopi arasındaki uyum, RBC'den daha iyiydi. Analizörler arasındaki uyum WBC'de ve RBC'de, manuel mikroskopiye göre daha iyiydi. Her ne kadar Urised 3, FUS-200 ve manuel mikroskopi sonuçları belli bir uyum içinde olsa da, otomatize yöntemlerin sonuçlarının manuel mikroskopi ile teyit edilmesi, özellikle de kesme değerlerine yakın patolojik örnekler için faydalıdır.

Anahtar kelimeler: Otomatik idrar sedimenti analizörü, DIRUI FUS-200, Urised 3, manuel idrar sedimenti analizi, karşılaştırmalı performans analizi
Received: 3 April 2019

Accepted: 4 September 2019 Online First: 27 September 2019

Corresponding Author: E. Yalcinkaya

ORCID: 0000-0003-2205-4977 Istanbul Medeniyet University Goztepe Research ang Training Hospital,

Department of Biochemistry, Istanbul, Turkey

emreyalcinkaya34277@gmail.com

\section{H. Erman}

ORCID: 0000-0002-7482-2029

E. Kirac

ORCID: 0000-0003-3572-8117

A. Serifoglu

ORCID: 0000-0003-3357-3430

A. Aksoy

ORCID: 0000-0001-9695-8835

F.K. Isman

ORCID: 0000-0003-4278-4651

M.B. Cekmen

ORCID: 0000-0002-6042-3561

Istanbul Medeniyet University Goztepe Research ang Training Hospital,

Department of Biochemistry, Istanbul, Turkey 
E. Yalcınkaya et al. Comparative Performance Analysis of Urised 3 and DIRUI FUS-200 Automated Urine Sediment Analyzers and Manual Microscopic Method

\section{INTRODUCTION}

Urinalysis is one of the most important screening tests in clinical practice. Microscopic examination of urine samples is necessary for the evaluation of urinary system diseases ${ }^{1}$. Microscopic analysis of urine sediments is a time consuming method that requires experience. Several preanalytical and analytical processes contribute to its imprecision. These factors are related to sampling, centrifugation and inter-observer variability. Despite all these disadvantages, manual microscopy is the reference method for the evaluation of urine sediment ${ }^{2}$. The automated urinalysis can save labor and time and is more feasible for the high volume laboratory workload ${ }^{3,4}$. Two systems based on different technologies which are image-based and flow cytometry are available. We are currently using FUS200 in our laboratory. However, we plan to install a new system, Urised 3. The objective of this study is to compare DIRUI FUS-200 (DIRIU Industrial Co., China) and Urised 3 (77 Elektronika Kft, Budapest, Hungary) with manual microscopy and with each other, using similar parameters [cell or particle counts/ $\mu \mathrm{L}$ under HPF (high-power field)] for evaluation. Because we want to see if the Urised 3 has sufficient and better analytical and diagnostic performance with respect to FUS-200. Otherwise, it will not be advantageous to use Urised 3 instead of FUS200.

\section{MATERIALS and METHODS}

This study approved by the Istanbul Medeniyet University, Goztepe Training and Research Hospital, Clinical Studies Ethics Committee, (6 June 2017, 2017/0200).

\section{Sample}

This study was performed in the central laboratory of Istanbul Medeniyet University Goztepe Training and Research Hospital. The laboratory has large sample volume and workflow. We performed this study using 440 urine samples in June 2017. We collected the urine samples in sterile, preservati- ve and antiseptic-free containers and transferred them into test tubes. Specimens were analyzed consecutively using these two automated analyzers and a standardized manual microscopy (by a single experienced technician) within 2 hours after submission to the laboratory. Since two urine samples were insufficient for evaluation using three devices, and their manual microscopic analysis could not be performed so they were not included in the analysis.

\section{Automated urine analyzers}

The analytical principle of the DIRUI FUS-200 is based on flow cell digital imaging and identification using software. As the urine passes through the flow cell, it is illuminated by a special light source, and the images are recorded by a digital camera placed into the eyepiece of the microscope and then they are login a computer-based system. The software classifies these images and displays them on the screen for the evaluation of images of these sediments by the operator.

The analytical principle of the Urised 3 is imagebased microscopic analysis of the urine sediment. The Urised 3 analyzer pipettes urine samples into an individual disposable cuvette without any reagents. The filled cuvette is centrifuged at 2000 rpm for 10 seconds. An automated built-in camera then takes 15 images of the settled monolayer of urine particles. Images are recorded in three types, including bright-field, phase contrast, and composite. Images are then evaluated by the Auto Image Evaluation Module, an automatic, real-time, image processing software. After the images are obtained, the operator can evaluate particles from the images displayed on the screen.

\section{Manual method}

We centrifuged all urine specimens in a conical measuring tube to measure urine volume at $400 \mathrm{~g}$ for 5 minutes and discarded supernatant leaving $200 \mu \mathrm{l}$ of sediment for further analysis. The remaining $200 \mu$ of urine specimen was resuspended and $20 \mu \mathrm{l}$ of sediment was pipetted onto a micros- 
cope slide (Olympus CX41RF) and covered with a coverslip (20 mm x $20 \mathrm{~mm}$ ) for standardized conventional urine sediment analysis. We counted number of RBCs and WBCs on 10 small squares under 400x magnification and gave the results as an average per HPF and classified as shown in Table 1 . We converted these numbers as cells per liter according to the following formula:

$$
\text { Cells } \times 10^{6} / L=\frac{n \times V_{\text {ol }} \text { Centr }}{\left(\frac{V_{\text {olside }}}{\text { HPF }}\right) \times \operatorname{Vol}_{\text {Sube }}}
$$

Table 1. Reference values of urine WBC and RBC.

\begin{tabular}{llllll}
\hline & & \multicolumn{4}{c}{ Positive } \\
\cline { 3 - 6 } Cells/HPF & Negative & Few & Moderate & High & Many \\
\hline WBC & $\leq 5$ & $6-10$ & $11-20$ & $21-50$ & $>50$ \\
RBC & $\leq 5$ & $6-10$ & $11-20$ & $21-50$ & $>50$ \\
& & & & & \\
\hline
\end{tabular}

WBC: white blood cell; RBC: red blood cell; HPF: high power field (x400)

In this transformation formula, $\mathrm{n}$ is the mean count of cells/HPF, HPF slide $_{\text {is }}$ " the ratio of area of the slide and area of one HPF". Vol ${ }_{\text {Centr }}$ is the volume of the pellet after centrifugation, $\mathrm{Vol}_{\text {Tube }}$ is the total urine volume in the test tube and $\mathrm{Vol}_{\text {Slide }}$ is the volume under the coverslip $\left(20 \times 10^{-6} \bigotimes\right)^{5}$.

\section{Study: Precision, Linearity, Comparison}

The between-run, within-run precisions and linearity were determined according to the CLSI protocols for the instrument Urised 3 for $R B C$ and WBC counts and for the instrument FUS-200 for total particle counts because of the features of different materials used for internal quality control ${ }^{6,7}$. Two levels of control materials were run 20 times on the same day for within-run precision study; twice daily on 20 separate days in duplicate for between-run precision study. The imprecision was stated as the coefficient of variation (CV\%). For stability reasons, instead of urine samples, Kova Liqua-Trol level 1 and level 2 control materials (fixed $\mathrm{RBC}$ and $\mathrm{WBC}$ ) were used for the Urised 3; and negative and positive control samples (par- ticles) were used for the FUS-200. To determine linearity for WBC, erythrocyte- lysed whole blood samples were used as high level samples. Saline was used as the blank sample. We mixed blank and high level specimen in ratios of $0: 4,1: 3,2: 2$, 3:1 and 4:0; and these mixtures were run for five times. Detection capabilities of the FUS-200 and Urised 3 were calculated according to EP17-A2 ${ }^{8}$.

\section{Data Analysis}

Deming Regression analysis was performed to establish differences between the analyzers. We classified the samples semi-quantitatively $(\leq 5$, $6-10,11-20,21-50,>50$ cells/HPF) and as positive, and negative ( $\leq 5$ vs $>5$ cells/HPF) according to erythrocyte and leukocyte counts ${ }^{9-11}$. Within the same grade Cohen's kappa coefficients were calculated for concordance between the methods and the McNemar test was used to measure changes in the distribution of two dichotomous variables. Values for Cohen's kappa coefficient were defined as poor (0-0.20), fair (0.21-0.40), moderate $(0.41-0.60)$, good $(0.61-0.80)$ and very good (0.81-1.00) agreement ${ }^{12}$. We determined the diagnostic power of both devices for RBC and WBC with reference to manual microscopy. EP Evaluator (David G. Rhoads Associates, Kennett Square, PA) was used for statistical analysis. P values of $\leq 0.05$ value were considered as significant test results. The diagnostic performance parameters; sensitivity, specificity, positive (PPVs) and negative predictive values (NPVs); were determined.

\section{RESULTS}

\section{Precision, Linearity, Comparison}

The reproducibility of the FUS-200 and Urised 3 were shown in Table 2. WBC showed good linearity up to 1090 cells $/ \mu \mathrm{L}$ with the following regression equations:

$Y=0.925 X-2.4 \quad\left(R^{2}=0.99\right)$ for the FUS-200 and $Y=1.159 X+16.67\left(R^{2}=0.97\right)$ for the Urised $3(F i-$ gure 1).

We compared the FUS-200, Urised 3 and manual 
E. Yalcınkaya et al. Comparative Performance Analysis of Urised 3 and DIRUI FUS-200 Automated Urine Sediment Analyzers and Manual Microscopic Method

Table 2. Results of precision study of FuS-200 and Urised 3.

\begin{tabular}{|c|c|c|c|c|c|c|c|c|c|}
\hline \multirow[b]{3}{*}{ Analyzer } & \multirow[b]{3}{*}{ Particle/pL } & \multicolumn{4}{|c|}{ Within-run Imprecision } & \multicolumn{4}{|c|}{ Between-run Imprecision } \\
\hline & & \multicolumn{2}{|c|}{ Low Level } & \multicolumn{2}{|c|}{ High Level } & \multicolumn{2}{|c|}{ Low Level } & \multicolumn{2}{|c|}{ High Level } \\
\hline & & Mean \pm SD & CV\% & Mean \pm SD & CV\% & Mean \pm SD & CV\% & Mean \pm SD & CV\% \\
\hline FUS-200 & Particle & $0^{*}$ & * & $993.05 \pm 25.46$ & 2.56 & $0^{*}$ & * & $1001.4 \pm 32.0$ & 3.4 \\
\hline Urised 3 & RBC & $0^{*}$ & * 238 & $72.16 \pm 15.85$ & 22 & $0^{*}$ & * & $44.77 \pm 11.02$ & 24.61 \\
\hline & WBC & $9.67 \pm 2.3$ & 23.8 & $73.99 \pm 14.19$ & 19.2 & $2.2 \pm 0.96$ & 44.06 & $140.1 \pm 31.14$ & 22.23 \\
\hline
\end{tabular}

* These values could not be calculated because the average cell count was $O$ RBC: red blood cell; WBC: white blood cell; CV: coefficient of variation
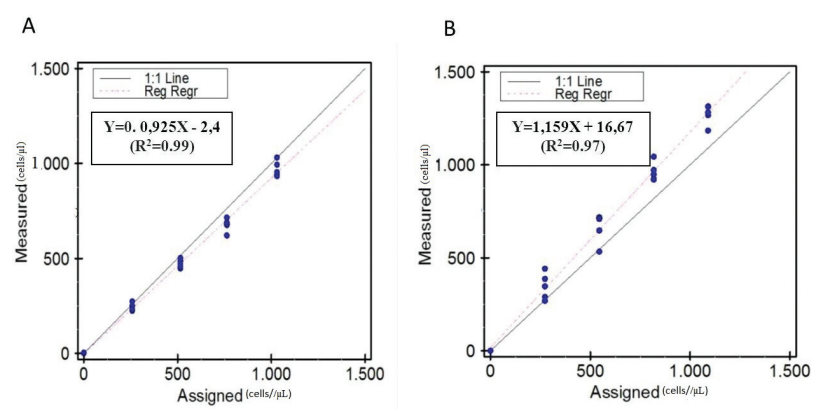

Figure 1. Linearity of FUS-200 (A) and Urised 3 (B) for WBC (cells/pl).

microscopy results for method comparison study. The Deming regression analysis was performed for RBC (range: 0 -2695 cells $/ \mu \mathrm{L}$ ) and WBC (range: $0-1110$ cells $/ \mu \mathrm{L}$ ) by comparing FUS-200, Urised 3 and manual microscopy methods (Figure 2) (Table 3).

The concordance between the manual method and automated analyzers was also comparatively evaluated (Tables 4, 5, 6, 7, and 8). When we evaluated the results according to positive and negative groups, the concordance rates between the manual method and automated analyzers are summarized in Table 9.

When the data were analyzed considering the positive and negative results, the FUS-200 and manual method did not differ for WBC counts (McNemar test; $\mathrm{P}=0.369$ ). Overall, the non-concordant results could have affected $7.08 \%$ of all diagnoses. Comparing the WBC counts of the Urised 3 with manual method, there was a significant difference in classification (McNemar test; $\mathrm{P}<0.001$ ) and $9.59 \%$
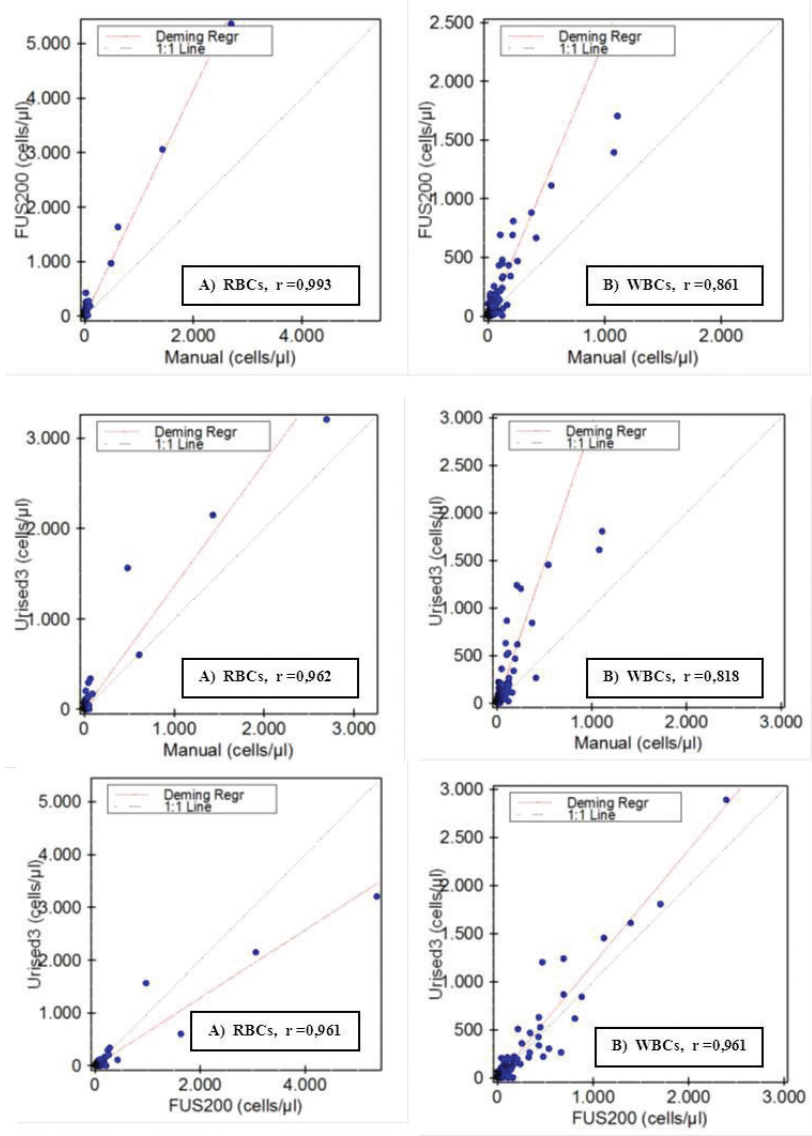

Figure 2. Deming regression analysis for RBCs (A) and WBCs (B) among the FUS-200, Urised 3 and manual microscopy.

of the results were non-concordant. Analysis of the data showed 7\% non-concordance between automated techniques (McNemar test; $\mathrm{P}<0.01$ ).

RBC counts differed significantly between the FUS200 and manual methods considering the positive and negative results (McNemar test; $\mathrm{P}<0.001$ ); non-concordance was $14.16 \%$. The Urised 3 and 
Table 3. Deming regression analysis between FUS-200 and Urised 3 for RBC and WBC.

\begin{tabular}{lllll}
\hline & Manual vs FUS-200 & Manual vs URISED3 & FUS-200 vs URISED3 \\
\hline WBC & Slope & $2.354(2.238$ to 2.469$)$ & $2.946(2.783$ to 3.109) & $1.186(1.155$ to 1.217$)$ \\
& Intercept & $-9.821(-20.695$ to 1.053$)$ & $-18.482(-33.822$ to 3.141$)$ & $-4.159(-10.257$ to 1.940$)$ \\
& Correlation coefficient & 0.861 & 0.818 & 0.961 \\
& Bias* & 24.358 & 30.645 & 5.208 \\
RBC & Slope & $2.069(2.045$ to 2.093$)$ & $1.362(1.326$ to 1.398$)$ & $0.643(0.626$ to 0.661$)$ \\
& Intercept & $8.311(4.582$ to 12.041$)$ & $2.793(-2.737$ to 8.322$)$ & $-2.148(-7.451$ to 3.155$)$ \\
& Correlation coefficient & 0.993 & 0.962 & 0.961 \\
& Bias* (counts/pl) & 28.446 & 9.616 & -18.503
\end{tabular}

* Mean difference between the cell counts

Table 4. Comparison of FUS-200, Urised 3 and manual WBC counts.

\begin{tabular}{|c|c|c|c|c|c|c|c|c|c|c|c|c|}
\hline Manual (cells/HPF) & \multicolumn{6}{|c|}{ FUS-200 (cells/HPF) } & \multicolumn{6}{|c|}{ URISED3 (cells/HPF) } \\
\hline $6-10$ & 9 & 12 & 7 & 4 & 0 & 32 & 8 & 9 & 6 & 9 & 0 & 32 \\
\hline $11-20$ & 3 & 1 & 4 & 7 & 1 & 16 & 1 & 1 & 4 & 8 & 2 & 16 \\
\hline $21-50$ & 1 & 2 & 2 & 5 & 11 & 21 & 1 & 1 & 1 & 8 & 10 & 21 \\
\hline
\end{tabular}

Table 5. Comparison of FUS-200, Urised 3 and manual RBC counts.

\begin{tabular}{|c|c|c|c|c|c|c|c|c|c|c|c|c|}
\hline \multirow[b]{2}{*}{ Manual (cells/HPF) } & \multicolumn{6}{|c|}{ FUS-200 (cells/HPF) } & \multicolumn{6}{|c|}{ URISED3 (cells/HPF) } \\
\hline & $0-5$ & 6-10 & 11-20 & 21-50 & $>50$ & Total & $0-5$ & $6-10$ & 11-20 & $21-50$ & $>50$ & Total \\
\hline $0-5$ & 362 & 34 & 21 & 3 & 1 & 421 & 336 & 3 & 0 & 0 & 0 & 339 \\
\hline $6-10$ & 3 & 0 & 3 & 2 & 0 & 8 & 19 & 11 & 1 & 0 & 0 & 31 \\
\hline $11-20$ & 0 & 0 & 0 & 5 & 0 & 5 & 2 & 10 & 10 & 0 & 0 & 22 \\
\hline $21-50$ & 0 & 0 & 0 & 0 & 0 & 0 & 1 & 0 & 7 & 18 & 0 & 26 \\
\hline$>50$ & 0 & 0 & 0 & 0 & 4 & 4 & 1 & 0 & 0 & 2 & 17 & 20 \\
\hline Total & 365 & 34 & 24 & 10 & 5 & 438 & 359 & 24 & 18 & 20 & 17 & 438 \\
\hline
\end{tabular}

Table 6. Comparison of FUS-200 and Urised 3 WBC.

\begin{tabular}{lllllll}
\hline & \multicolumn{6}{c}{ URISED3 (cells/HPF) } \\
\cline { 2 - 7 } FUS-200 (cells/HPF) & $\mathbf{0 - 5}$ & $\mathbf{6 - 1 0}$ & $\mathbf{1 1 - 2 0}$ & $\mathbf{2 1 - 5 0}$ & $\mathbf{5 0 0}$ & Total \\
\hline $0-5$ & 334 & 19 & 5 & 0 & 0 & 358 \\
$6-10$ & 4 & 10 & 11 & 3 & 0 & 28 \\
$11-20$ & 2 & 1 & 4 & 10 & 0 & 17 \\
$21-50$ & 1 & 1 & 2 & 11 & 3 & 18 \\
$>50$ & 0 & 0 & 0 & 2 & 17 & 19 \\
Total & 341 & 31 & 22 & 26 & 20 & 440 \\
\hline
\end{tabular}

Table 7. Comparison of FUS-200 and Urised 3 RBC.

\begin{tabular}{lllllll}
\hline & \multicolumn{6}{c}{ URISED $\mathbf{3}$ (cells/HPF) } \\
\cline { 2 - 7 } FUS-200 (cells/HPF) & $\mathbf{0 - 5}$ & $\mathbf{6 - 1 0}$ & $\mathbf{1 1 - 2 0}$ & $\mathbf{2 1 - 5 0}$ & $\mathbf{7 5 0}$ & Total \\
\hline $0-5$ & 353 & 7 & 6 & 0 & 0 & 366 \\
$6-10$ & 30 & 2 & 3 & 0 & 0 & 35 \\
$11-20$ & 13 & 5 & 4 & 2 & 0 & 24 \\
$21-50$ & 3 & 2 & 0 & 3 & 2 & 10 \\
$>50$ & 0 & 0 & 0 & 1 & 4 & 5 \\
Total & 399 & 16 & 13 & 6 & 6 & 440 \\
\hline
\end{tabular}


E. Yalcınkaya et al. Comparative Performance Analysis of Urised 3 and DIRUI FUS-200 Automated Urine Sediment Analyzers and Manual Microscopic Method

Table 8. Concordance of urinalysis within the same grade.

\begin{tabular}{|c|c|c|c|c|}
\hline & \multicolumn{2}{|l|}{ WBC } & \multicolumn{2}{|l|}{$\mathbf{R B C}$} \\
\hline & Concordance rate (\%) & Kappa & Concordance rate $(\%)$ & Kappa \\
\hline Manual vs FUS-200 & 84.9 & ${ }^{\mathrm{m}} 0.53$ & 83.6 & P0.17 \\
\hline Manual vs Urised 3 & 81.7 & ${ }^{\mathrm{m}} 0.48$ & 89.5 & $\mathrm{~s} 0.71$ \\
\hline FUS-200 vs Urised 3 & 85.5 & m0.59 & 83.2 & f0.30 \\
\hline
\end{tabular}

p: poor agreement, f: fair agreement, m: moderate agreement, g: good agreement

Table 9. Concordance of urinalysis within the same condition (negative-positive).

\begin{tabular}{|c|c|c|c|c|}
\hline & \multicolumn{2}{|l|}{ WBC } & \multicolumn{2}{|l|}{$\mathbf{R B C}$} \\
\hline & Concordance rate (\%) & Kappa & Concordance rate (\%) & Kappa \\
\hline Manual vs FUS-200 & 92.9 & $\mathrm{~s} 0.76$ & 85.8 & 0.27 \\
\hline Manual vs Urised 3 & 90.4 & s0.70 & 92.5 & f0.39 \\
\hline FUS- 200 vs Urised 3 & 93 & s0.79 & 86.6 & ${ }^{\mathrm{m}} 0.42$ \\
\hline
\end{tabular}

f: fair agreement, m: moderate agreement, g: good agreement

Table 10. Diagnostic performance of FUS-200 and Urised 3.

\begin{tabular}{|c|c|c|c|c|c|}
\hline Cells & Method & Sensitivity (\%) & Specificity (\%) & PPV (\%) & NPV \\
\hline \multirow[t]{2}{*}{ WBC } & FUS-200 & 82.9 & 95 & 77.8 & 96.4 \\
\hline & URISED 3 & 86.8 & 91.2 & 67.4 & 97.1 \\
\hline \multirow[t]{2}{*}{ RBC } & FUS-200 & 82.4 & 86 & 19.2 & 99.2 \\
\hline & URISED 3 & 70.6 & 93.4 & 30 & 98.7 \\
\hline
\end{tabular}

PPV: Positive Predictive Value, NPV: Negative Predictive Value

manual methods showed a similar pattern (McNemar test $\mathrm{P}<0.001$ ), and non-concordance was $7.53 \%$. Both automated methods showed $13.4 \%$ non-concordance (McNemar test $\mathrm{P}<0.001$ ). Diagnostic performance parameters were summarized in Table 10.

\section{DISCUSSION}

To our knowledge, a comparison study between the instruments FUS-200 and Urised 3 is not available in the literature. We classified the WBC and RBC counts according to the clinical decision limits to compare manual microscopy with the automated analyzers. In relation to clinically positive and negative results, the concordance between the manual method and automated analyzers ranged from fair to good for WBC and RBC counts.
Each assessment procedure for urine sediment has its own advantages and disadvantages. Although manual microscopy has a lot of methodological problems and many factors reduce its precision and accuracy, it is accepted as the reference method for urine urinalysis ${ }^{13}$. Automated urine analyzers that use several analytic techniques have been developed to deal with disadvantages of manual microscopy.

In accordance with the literature, we found that our results were more accurate in urine sediments having higher cell counts ${ }^{14-16}$. It is accepted that automated analyzers reduce the time spent on manual examination, as reported in some studies ${ }^{17,18}$. A study which was performed with 214 urine samples, conventional microscopy and a flow cytometry-based UF-1000i device showed a nearly perfect concordance ${ }^{19}$.

In our study, we found the precision of Urised 3 lower with respect to another study ${ }^{16}$. Our imprecision was higher than the results reported by Bottini et al., Akin et al. and Zaman et al. in previous studies of Urised ${ }^{9,14,20}$. The precision of the FUS-200 in this study was lower than that reported by Ince et. al. ${ }^{15}$; similar to the precision of UX- 
2000 reported by S. Laiwejpithaya et. al. ${ }^{16}$ and precision of Sysmex UF-1000i reported by Lee et al. ${ }^{21}$. Overall, the FUS-200 showed better precision profile than the Urised 3 due to quality-control sample characteristics. However, both analyzers had higher precision when compared to the conventional microscopy with respect to the results reported by Chien et al. ${ }^{22}$ and Jiang et al. ${ }^{23}$. Deming regression analyzes of both analyzers showed good correlation ranging from $r=0.818$ to $r=0.993$ for $R B C$ and WBC. Although the same urine specimens were evaluated, differences in measured concentration of RBC and WBC between instruments may be due to different analytic technologies. Differences between the results of analyzers don't have to be disregarded. The slopes and intercepts were outside of the confidence interval of 1 and 0 , respectively (Table 3 ). If both analyzers and the same reference intervals are to be used in the same laboratory, it is necessary to use a conversion factor to eliminate the effects of these differences ${ }^{24}$.

We observed better concordance rate within the same grade for WBC compared to the results reported by Ince et al. and similar concordance between the FUS-200 and manual microscopy considering the RBC results. Degree of concordance for positive results was better for $\mathrm{WBC}$ and worse for RBC than the results reported by Ince et al. ${ }^{15}$. Between the Urised 3 and manual microscopy, concordance rate within the same grade was lower for WBC and RBC; degree of concordance for positive results was similar for $\mathrm{WBC}$ and lower for $\mathrm{RBC}$ with respect to the study of S. Laiwejpithaya et al. ${ }^{16}$.

Semi-quantitative analyzes of WBC and RBC showed a lower agreement compared to the results reported by $\mathrm{Nagy}^{25}$. In terms of semi-quantitative analysis, Urised 3 showed very good agreement rates. Kappa values showed very good agreement for RBC; and moderate agreement for WBC. The FUS-200 also had very good agreement rates, but the kappa values were different. They were fair for
RBC; moderate for WBC. NPV of Urised 3, ${ }^{10,16,26}$; and FUS-200 ${ }^{10,15}$. for RBC and WBC was good as reported by other studies PPV of the Urised 3 for WBC and RBC was low as reported by Yuksel et al. ${ }^{10}$. PPV of the FUS-200 for RBC and WBC were worse than that was reported by Ince et al. ${ }^{15}$ and similar to PPV reported by Yuksel et al. ${ }^{10}$. These results could be due to urine centrifugation procedure before analysis that may form aggregates or produce cell lysis ${ }^{27}$. The NPV $s$ of the devices were similar or better than their PPVs. These results showed that the two devices have low falsenegative results but higher false positive results.

The methods gave some inconsistent results that may mislead clinical diagnoses, particularly for urine samples with cell counts close to the cutoff values (6-10 cells/HPF). We observed clinical non-concordance similar to the results reported by Akin et al. ${ }^{9}$. Other studies have also reported similar clinical non-concordant results ${ }^{11,28}$.

In summary, Urised 3 and FUS-200 give reproducible results and analyze great numbers of urine samples. Urised 3 was more specific for RBC and more sensitive for WBC than FUS-200. FUS-200 and Urised 3 had lower PPVs for WBC and RBC relative to NPVs. Both analyzers had better PPVs for WBC rather than RBC. FUS-200 had higher PPV for WBC than Urised 3. FUS-200 had lower PPV for RBC than Urised 3. FUS-200 and Urised 3 had almost perfect and similar NPV for both of the cell types. Lesser number of pathological samples is the limitation of this study.

\section{CONCLUSION}

Urised 3 and FUS-200 had almost similar performance rates compared to standardized manual microscopy considering the clinically positive and negative concordance rates for RBC and WBC counts. So it is important to confirm the results by manual sediment analysis, especially for pathological cases based on the clinically decided cut-off limits. 
E. Yalcınkaya et al. Comparative Performance Analysis of Urised 3 and DIRUI FUS-200 Automated Urine Sediment Analyzers and Manual Microscopic Method

\section{Acknowledgements}

We are pleased to acknowledge the technical assistance of laboratory technicians.

\section{REFERENCES}

1. Fogazzi GB. The urinary sediment. An integrated view: Penerbit Buku Kompas; 2010.

2. Winkel P, Statland BE, Jorgensen K. Urine microscopy, an ill-defined method,examined by a multifactorial technique. Clin Chem. 1974;20:436-9.

3. Christenson RH, Tucker JA, Allen E. Results of dipstick tests, visual inspection, microscopic examination of urine sediment, and microbiological cultures of urine compared for simplifying urinalysis. Clin Chem. 1985;31:448-50.

4. Clemens AH, Hurtle RL. Automatic system for urine analysis. I. System design and development. Clin Chem. 1972;18(8):789-93.

5. Rabinovitch A, Arzoumanian L, Curcio KM, Dougherty B, Halim A. CLSI. Urinalysis; Approved Guideline-Third Edition. CLSI document GP16-A3 C. Wayne, PA: Clinical and Laboratory Standards Institute, 2009.

6. Tholen DW, Kallner A, Kennedy JW, Krouwer JS, Meier K. CLSI. Evaluation of precision performance of quantitative measurement methods; Approved Guideline-Second Edition. CLSI document EPO5-A2. Wayne, PA: Clinical and Laboratory Standards Institute; 2004.

7. Tholen DW, Kroll M, Astles JR, et al. CLSI. Evaluation of the linearity of quantitative measurement procedures: a statistical approach; Approved Guideline. CLSI document EP06A Wayne, PA: Clinical and Laboratory Standards Institute; 2003.

8. Pierson-Perry JF, Vaks JE, Durham AP, et al. CLSI. Evaluation of Detection Capability for Clinical Laboratory Measurement Procedures; Approved Guideline-Second Edition. CLSI document EP17-A2 Wayne, PA: Clinical and Laboratory Standards Institute; 2012.

9. Akin OK, Serdar MA, Cizmeci Z, Genc O, Aydin S. Comparison of LabUMat-with-UriSed and iQ200 fully automatic urine sediment analysers with manual urine analysis. Biotechnol Appl Biochem. 2009;53(Pt 2):139-44. [CrossRef]

10. Yüksel H, Kiliç E, Ekinci A, Evliyaoğlu O. Comparison of fully automated urine sediment analyzers H800-FUS100 and LabUMat-UriSed with manual microscopy. J Clin Lab. Anal. 2013;27(4):312-6. [CrossRef]

11. Shayanfar N, Tobler U, von Eckardstein A, Bestmann L. Automated urinalysis: first experiences and a comparison between the Iris iQ200 urine microscopy system, the Sysmex UF-100 flow cytometer and manual microscopic particle counting. Clin Chem Lab Med. 2007;45(9):1 251-6. [CrossRef]

12. Cohen J. A Coefficient of agreement for nominal scales. Educational and Psychological Measurement. 1960;20(1):37-46. [CrossRef]

13. Carlson DA, Statland BE. Automated urinalysis. Clin Lab Med. 1988;8:449-61. [CrossRef]

14. Zaman Z, Fogazzi GB, Garigali G, Croci MD, Bayer G, Kránicz T. Urine sediment analysis: Analytical and diagnostic performance of sediMAX - a new automated microscopy image-based urine sediment analyser. Clin Chim Acta. 2010;411:147-54. [CrossRef]

15. İnce FD, Ellidağ HY, Koseoğlu M, Şimşek N, Yalçın H,
Zengin MO. The comparison of automated urine analyzers with manual microscopic examination for urinalysis automated urine analyzers and manual urinalysis. Pract Lab Med. 2016;5:14-20. [CrossRef]

16. Laiwejpithaya S, Wongkrajang P, Reesukumal K, et al. UriSed 3 and UX-2000 automated urine sediment analyzers vs manual microscopic method: A comparative performance analysis. J Clin Lab Anal. 2018;32: e22249. [CrossRef]

17. Tworek JA, Wilkinson DS, Walsh MK. The rate of manual microscopic examination of urine sediment: a College of American Pathologists Q-Probes study of 11,243 urinalysis tests from 88 institutions. Arch Pathol Lab Med. 2008;132:1868-73. [CrossRef]

18. Zaman Z. Automated urine screening devices make urine sediment microscopy in diagnostic laboratories economically viable. Clin Chem Lab Med. 2015;53(Suppl 2):s1509-11. [CrossRef]

19. Manoni F, Tinello A, Fornasiero L, et al. Urine particle evaluation: a comparison between the UF-1000i and quantitative microscopy. Clin Chem Lab Med. 2010;48:110711. [CrossRef]

20. Bottini PV, Martinez MH, Garlipp CR. Urinalysis: comparison between microscopic analysis and a new automated microscopy image-based urine sediment instrument. Clin Lab. 2014;60:693-7. [CrossRef]

21. Lee W, Ha JS, Ryoo NH. Comparison of the Automated cobas u 701 Urine Microscopy and UF-1000i Flow Cytometry Systems and Manual Microscopy in the Examination of Urine Sediments. J Clin Lab Anal. 2016;30:663-71. [CrossRef]

22. Chien TI, Kao JT, Liu HL, et al. Urine sediment examination: a comparison of automated urinalysis systems and manual microscopy. Clin Chim Acta. 2007;384:28-34. [CrossRef]

23. Jiang T, Chen P, Ouyang J, Zhang S, Cai D. Urine particles analysis: performance evaluation of Sysmex UF-1000i and comparison among urine flow cytometer, dipstick, and visual microscopic examination. Scand J Clin Lab Invest. 2011;71:30-7. [CrossRef]

24. Regeniter A, Haenni V, Risch L, et al. Urine analysis performed by flow cytometry: reference range determination and comparison to morphological findings, dipstick chemistry and bacterial culture results--a multicenter study. Clin Nephrol. 2001;55:384-92.

25. Nagy E. Evaluation of the UriSed 3 automated urine microscopy analyzer: Clinical Study Made in the Polyclinic of the Hospitaller Brothers of St. John of God in Budapest, Central Laboratory. Budapest. 2015.

26. Mayo S, Acevedo D, Quiñones-Torrelo C, Canós I, Sancho $\mathrm{M}$. Clinical laboratory automated urinalysis: comparison among automated microscopy, flow cytometry, two test strips analyzers, and manual microscopic examination of the urine sediments. J Clin Lab Anal. 2008;22:262-70. [CrossRef]

27. Íñigo M, Coello A, Fernández-Rivas G, et al. Evaluation of the SediMax automated microscopy sediment analyzer and the Sysmex UF-1000i flow cytometer as screening tools to rule out negative urinary tract infections. Clin Chim Acta. 2016;456:31-5. [CrossRef]

28. Khejonnit V, Pratumvinit B, Reesukumal K, Meepanya S, Pattanavin C, Wongkrajang P. Optimal criteria for microscopic review of urinalysis following use of automated urine analyzer. Clin Chim Acta. 2014;439:1-4. [CrossRef] 